\title{
VIOLÊNCIA NOS ESPAÇOS DE TRABALHO TERCEIRIZADOS: exclusões, segregações e discriminações
}

Any Ávila Assunção

Curso: Mestrado em Sociologia

Data de Defesa da dissertação: 15 de março de 2005

Orientadora: Prof ${ }^{a}$ Dr $^{a}$ Lourdes Maria Bandeira

\section{Resumo}

Esta pesquisa analisa a produção e a intensificação dos atos e estados de violência nas relações de trabalho em espaços terceirizados. Para tanto, foi realizado um estudo comparativo das relações laborais dos(as) trabalhadores(as) de limpeza pública urbana do Distrito Federal estabelecidas antes e após a terceirização destes serviços, focalizando um contraste entre ambas as situações, sob o olhar das diversas modulações materiais e simbólicas da presença da violência.

Para o desenvolvimento desta pesquisa, além da elaboração do arcabouço teórico em que se fundamenta, foram investigados vários aspectos das duas organizações estudadas - "Entidade A", ente público titular dos serviços de limpeza urbana do Distrito Federal; e "Entidade B", empresa privada terceirizada que atualmente executa tais serviços: os regimes jurídicos aplicáveis; as condições de trabalho; alguns instrumentos de proteção legal ao(à) trabalhador(a) e os registros de acidentes de trabalho.

Os resultados da investigação apontam que o "alegado" aumento da produtividade e a busca de imprimir mais eficiência ao serviço público de limpeza urbana, com a adoção do processo de 
terceirização, intensificam as práticas e os episódios de violência nas relações de trabalho, cujo preço social é o desmanche das conquistas sociais.

Palavras-chave: violência, trabalho, terceirização, serviço público. 